\title{
The Mackie Ethnological Expedition to Central Africa.
}

\section{$\mathrm{T}$} HE REV. J. ROSCOE, the leader of the Mackie Ethnological Expedition to Central Africa, has recently returned to this country after an absence of more than eighteen months. The expedition, which was made possible by a generous donation from Sir Peter Mackie, placed at the disposal of the Royal Society, had for its object the investigation of the laws, customs, and beliefs of the native tribes under British rule in Central Africa, particularly in the Uganda Protectorate, in accordance with a scheme which had been planned and urgently advocated for many years by Sir James Frazer, but for which funds had hitherto been wanting. The tribes which the expedition proposed to investigate had been very little modified by contact with civilisation, and it was felt that a detailed examination of their institutions and beliefs would not only add very materially to our scientific knowledge, but would also conduce to the good government and economic development of the country in the future.

The expedition left this country in the spring of I9I9. The first part of its labours was devoted to the study of the Bahima of Ankole, an important pastoral tribe, in the western part of the Uganda Protectorate. During a stay of three months Mr. Roscoe gathered an immense amount of detailed information relating to the clan and totem organisation and tabus, the system of government, and the beliefs and rituals connected with the care of cattle and the milk, which play an important part in regulating the life of the community.

From Ankole the expedition moved to Kigezi, where a short stay was made for the purpose of studying the Bakyiga, a large and fierce mountain tribe of many clans, partly pastoral, partly agricultural. The tribe is believed to be the original stock, which the Bahima were never able to conquer. This is borne out by the fact that they are of the same type as the slaves in Ankole and the lower order of people in Bunyoro.

On leaving Kigezi the expedition set out for Bunyoro, proceeding westward to the arm connecting the two lakes Edward and George, and then northward along the line of these lakes and Lake Albert-a country very little known, which was found to be of extraordinary beauty.
In the course of a short rest of a week a superficial examination of the Bamba and Bakonja of Mount Luenzori was made. The expedition then proceeded from Port Ntoroko by steamer to Butiaba, the port for Masindi, the capital of Bunyoro, where it entered upon the second and, as it proved, the most fruitful part of its labours.

The King of Bunyoro gave every assistance to the expedition. He is now a Christian, but as the repository of the tradition and practice of the religion of the people his knowledge, which was placed freely at Mr. Roscoe's disposal, proved of inestimable value. The Bunyoro tribe, or rather nation, consists of two distinct races, the Bahuma and the Bairu-the latter a subject people of agricultural peasants belong. ing to Bantu stock and descended from the original inhabitants of the country; the former a purely pastoral people akin to the Gallas, who form a ruling aristocracy, descended from a people which invaded and conquered the country from the north. Intermarriage between the two races is rare, though not absolutely forbidden. The greater part of the life of the king is, or rather used to be, devoted to ceremonial observances connected with his cattle in order to increase the progeny of man and beast and the supply of food. So much was this the case that the whole of his day was mapped out for him, and he rarely, if ever, quitted his kraal. One peculiar feature of the ritual was a daily meal at which he partook of sacred beef. The royal cook knelt before the king and placed four pieces of meat in the king's mouth with a special fork, taking care not to let the fork touch the roval teeth under penalty of death.

From Masindi the expedition proceeded to Mount Elgon, where it made some further inquiries among the cannibal Bagesu, whom Mr. Roscoe had already visited and described. It had been intended originally to pass northward into Karamojo in order to investigate the Turkana, an interesting people, remarkable for their great stature, of whom very little in detail is known. Unfortunately, military operations which were being carried on in that region made that impossible. The expedition therefore turned to Busoga, and after a short stay there returned to Bunvoro, whence it started on its homeward iourney down the Nile.
E. N. F.

\section{The Indian School of Mining and Geology.}

THE recent decision of the Government of India to establish a School of Mining and Geology at Dhanbaid follows the recommendations of Sir Duncan McPherson's Committee of I $^{1} 3^{-14} 4$ on mining education, of the expert Committee which examined the system of mining education in England in $1914-4_{5}$, and of the Indian Industrial Commission of 1916-18. The site of the proposed school has caused some difference of opinion in the past. Thus the Calcutta University Commission enumerated the many advantages which Calcutta was believed to possess, but in finally deciding on Dhanbaid the Government of India has followed the recommendations of the three Committees, and come to a conclusion with which those who know local conditions best will cordially agree. Dhanbaid enjoys an excellent situation, and return visits to the coal-mines will occupy onlv a few hours; from Calcutta they would take at least thirty-six hours.

The provision at present made for mining education No. 2666 , VOL. IO6] in India comprises (I) courses at the Sibpur Engineering College, near Calcutta, and (2) evening classes on the coalfield. The existing provision for higher training in geology is even less satisfactory. The proposal is that the new school will be an institution of collegiate type, in which the highest form of teaching in the art of mining and its accessory sciences is to be undertaken, so that in time it will rank with similar institutions in this country, and give equal opportunities for the study of geology and mining in all their branches. Thus natives of India will eventually be able to obtain in their own country that specialised training which to-day is an essential qualification for the more responsible posts in the mining and geological professions.

With the school on the coalfield both students and staff will be in close contact with a well-developed mining industry, and the great desirability of having intimate relationship between the industry and mining education will be realised. Further, the teachers of 